\title{
Determinants of household electricity consumption in Greece: a statistical analysis
}

\author{
Dimitra Kotsila ${ }^{1}$ and Persefoni Polychronidou ${ }^{2,3^{*}}$ (D)
}

\author{
* Correspondence: polychr@es.ihu.gr \\ ${ }^{2}$ Department of Economics, \\ International Hellenic University, \\ Serres, Greece \\ ${ }^{3}$ Hellenic Open University, Patras, \\ Greece \\ Full list of author information is \\ available at the end of the article
}

\begin{abstract}
Over the last decades, the contemporary way of living, as well as the technology development, has increased the household electricity consumption. The excessive use of electricity has a negative impact on the environment, increasing the carbon footprint and contributing to the climate change. Governments are more and more concerned about the way our societies consume energy and are committed to reduce the greenhouse emissions. As the residential sector contributes significantly to energy use, it is crucial to investigate the socio-economic parameters, dwellings' characteristics, and climate conditions that determine the electricity consumption in households. The data of this study are collected from 1801 dwellings from all regions of Greece and two statistical models are built. Both of them conclude that the most significant determinants influencing the electricity consumption are the number of occupants, the size of the dwelling, the heating type, the heating and cooling hours, and the weather conditions.
\end{abstract}

Keywords: Electricity, Consumption, Determinants, Socio-economic, Statistical analysis

\section{Introduction}

In the last decades due to the increased demand and the improved lifestyle, energy demand in the residential sector has increased rapidly causing the policymakers' concern. The international climate negotiation is an opportunity for decision-makers to promote enhancement of energy efficiency and reduction of greenhouse emissions and set commitments for renewable energy consumption. The recent "2030 Energy Strategy" and the Paris climate conference (COP21) focus on the previous objectives to keep a global temperature rise this century below $2{ }^{\circ} \mathrm{C}$. According to IEA (2020a), based on the most recent data of 2018 in Greece, the CO2 emissions from fuel combustion only come from electricity and heat producers (46.8\%), transport (27.4\%), industry (8.1\%), other energy industries (8.1\%), residential (6.5\%), commercial and public services (1.6\%), and other (1.6\%).

In the last two decades, the Greek governments have given a high priority to the environmental protection; thus, they promoted the Renewable Energy Sources (RES). The main aim concerning the RES is to be able to participate in the electricity consumption for at least $40 \%$ by the end of 2020. Specifically, under the European Renewable Energy

(c) The Author(s). 2021 Open Access This article is licensed under a Creative Commons Attribution 4.0 International License, which permits use, sharing, adaptation, distribution and reproduction in any medium or format, as long as you give appropriate credit to the original author(s) and the source, provide a link to the Creative Commons licence, and indicate if changes were made. The images or other third party material in this article are included in the article's Creative Commons licence, unless indicated otherwise in a credit line to the material. If material is not included in the article's Creative Commons licence and your intended use is not permitted by statutory regulation or exceeds the permitted use, you will need to obtain permission directly from the copyright holder. To view a copy of this licence, visit http://creativecommons.org/licenses/by/4.0/. 
Directive 2009/28/EC (European Parliament and Council, 2009) and the Law 3851/ 2010 (Official Government Gazette, 2018), Greece needs to meet the following targets for RES contribution:

- $20 \%$ of the final energy consumption for heating and cooling

- $40 \%$ of the final electricity consumption

- $10 \%$ of the final energy consumption in transportation

According to the most recent provided data by IEA (2017), Greece has achieved its goal in the sector of heating and cooling (58.90\%), but is far from its aim in the other two sectors $(22.09 \%$ and $1.43 \%$, respectively). However, Greece has made an impressive progress in the electricity sector, thanks to the rapid growth in installed wind and solar parks and the decrease in the total electricity demand.

In 2019, RES and gas are the primary fuels of electricity production in Greece (IEA, 2020b). In particular, the total electricity production is based on RES (35.2\%), gas (35.2\%), coal (22.2\%), and oil (9.2\%), while in 2017 the corresponding percentages were the following: RES (25.1\%), gas (31\%), coal (34\%), and oil (10\%).

Policymakers must focus on the distribution of the electricity consumption, in order to detect and improve the most inefficient sectors. In 2018, the distribution of electricity consumption per sector has been the following: commercial and public services (36\%), residential (33.9\%), industry (25.1\%), agriculture/foster (4.6\%), and transport $(0.6 \%)$; it must be noted that this is similar in the last ten years (IEA, 2020c).

In the residential sector, the final energy consumption is used to heat the space (57\%), for lighting and appliances (20\%), for heater heating (12\%), for cooking (7\%), and for space cooling (4\%) (Eurostat, 2018).

Consumption per capita is an important indicator to observe the tendency of electricity consumption through the years, as it offers a clear view of the electricity that every individual consumes. In Greece, in 2014 the per capita electricity consumption was $5062.61 \mathrm{kWh} /$ capita while in 2010 was $5333.44 \mathrm{kWh} /$ capita and in 2008 was 5805.19 kWh/capita (DataBank, 2020). The economic crisis in Greece since 2008-2009 influenced the electricity consumption as in 2013 the average consumption fell to 5029 $\mathrm{kWh} /$ capita. Consumption per household is another indicator to monitor the electricity consumption in the residential sector. In 2000, the electricity per household (hh) was $3717 \mathrm{kWh} / \mathrm{hh}$, while in 2010 it was $4023 \mathrm{kWh} / \mathrm{hh}$ (World Energy Council, 2016).

The increasing trend of electricity consumption is a reality. Since the residential sector is one of the most demanding sectors regarding electricity consumption, it should be studied. Unfortunately, in Greece, the socio-economic parameters that influence the electricity consumption have never been extensively examined. From the previous studies, that are outlined in the "Literature review" section, the electricity consumption is relevant with demographic data, dwelling characteristics and geographical and climate conditions. This study analyzes the aforementioned parameters in Greece and it is based on real data from 1801 customers of a Greece's electricity provider. The variables and the methodology that are used in the current analysis are in line with the deep literature review that was conducted by Jones et al. (2015).

This paper is organized as follows: in the "Literature review" section, an overview of the literature review relevant for this study is included. A description of the regression 
models and the data sources is given in the "Method" section. In the "Results and discussion" section, the main results are summarized. Finally, the conclusions are presented in the "Conclusions" section.

\section{Literature review}

On the international stage, residential electricity consumption is a considerably studied subject. Relevant studies are sequenced with the oldest first and the most recent last.

\section{Studies regarding European countries}

Halicioglu (2007) examines how the energy demand in residential sector in Turkey was influenced from the price and income. The income positively influences the electricity demand and accelerates purchases of electrical goods and services. The price of electricity negatively influences the electricity demand, while the urbanization positively influences the electricity demand, as it provides greater access to electricity.

Gram-Hanssen (2011) points out that the user's practices influence the energy consumption. He examines 8500 detached houses in Denmark and he finds that the income, the size of the house, and the presence of teenagers (13-19 years old) all have a positive effect on electricity consumption.

Wiesmann et al. (2011) examine the relationship between the per capita electricity consumption and dwelling characteristics in Portuguese consumers. They conclude that the income, the appliance ownership, and the floor area have a positive influence on per capita electricity consumption. People who live in single-family houses and/or in urban households consume more electricity than those living in a block of flats and/or rural households. People per household, dwellings per building and more heating degree-days negatively influence the consumption per capita, since in colder regions households consume less electricity per capita than those in more moderate climates.

McLoughlin et al. (2012) examine the influence of dwelling and occupant characteristics on electricity consumption of 3941 Irish dwellings. Dwelling type, number of bedrooms, age of the head of household, and electrical appliances used for water heating and cooking have a positive effect on electricity consumption.

Bedir et al. (2013) point out that in Netherlands the household size, the dwelling type, and the duration of electrical appliances' use (such as dryers and washing machines) have significant effect on the electricity consumption. Also, in the Netherlands, Brounen et al. (2012) analyze data of 300,000 dwellings. The dwelling type affects electricity consumption as the detached and semi-detached houses consume more electricity per capita than row houses or apartments. Houses with children and especially those that have teenagers are found to have a positive effect on per capita electricity consumption. The income has positive influence whereas the number of persons in household has a negative effect on per capita electricity consumption.

\section{Studies regarding non-European countries}

Ndiaye and Gabriel (2011) analyze electricity consumption of 62 dwellings of Oshawa (Ontario, Canada). Number of residents, house status, type of fuel used to heat the pool, type of fuel used in the heating system, type of fuel used in the domestic hot water heater, type of air-conditioning, and number of air changes per hour at $50 \mathrm{~Pa}$ are 
found to have a positive effect on the electricity consumption. On the other hand, the average number of weeks that the family leaves for vacation and the existence or not of an air conditioning system have a negative effect on the electricity.

Sanquist et al. (2012) base their research on data from the Residential Energy Consumption Survey (RECS) conducted on 2005 in the USA. The air-conditioning, laundry usage, personal computers, climate zone of dwelling, and TV use significantly influence the electricity consumption. Kavousian et al. (2013) examine the residential electricity consumption of 952 US dwellings in a view of daily maximum and minimum. Daily minimum consumption is influenced by weather, location, dwelling size, and the number of refrigerators when daily maximum consumption is influenced by the use of appliances that consume a lot and the number of residents. In the summer model, the primary factor that influences the electricity consumption is the cooling degrees days.

Tewathia (2014) conducts a survey in Delhi to find the determinants of electricity consumption. The household income, the number and the usage of electrical appliances, the size of the house, the family size, time spent out of the house, and the higher educational level influence the monthly electricity consumption through all the seasons. The educational level has a negative relationship as the higher educated families tend to consume less electricity. Filippini and Pachauri (2004) analyze the electricity demand in urban Indian households. The price is inelastic in electricity demand, so the price is not an inhibiting factor in residential electricity consumption. The income, the size, the regions, and the degrees of urbanity have a significant influence into the electricity consumption. Dwellings with more residents and younger households head had the tendency to consume less electricity from those that had less elder people.

Jones et al. (2015) conduct a broad literature review to investigate the factors that influence or not the domestic electricity consumption. They study 62 factors as potential factors that determine the electricity consumption. In relation to socio-economic factors, the higher household and disposable income, the more occupants and presence of teenagers have a positive effect on electricity consumption. In relation to dwelling factors, the dwelling age, the number of rooms, the number of bedrooms, and the floor area influence the electricity consumption. Regarding appliance factors, the following ones have a positive effect: more appliances, the existence of desktop computer, television, electric oven, refrigerator, dishwasher, tumble dryer, and higher use of washing machines and tumble dryer.

Esmaeilimoakher et al. (2016) accomplish an introduction to the factors that influence the electricity consumption. Their analysis is based on a survey conducted in nine households of Perth of Western Australia. The main results are that the average annual electricity consumption per person per $\mathrm{m}^{2}$ floor area $\left(\mathrm{AAEC} / \mathrm{P} \mathrm{m}^{2}\right.$ ) has a negative correlation with the number of occupants and the dwellings size.

\section{Studies regarding Greece}

The research in the field of socio-economic determinants that influence electricity consumption in Greece is poor. There are a lot of works focused on macroeconomic factors that determine energy consumption. Only the study of Sardianou (2007) provides research that includes demographic data and examines electricity conservation behavior. 
Donatos and Mergos (1991) examine the residential electricity demand in Greece during the period 1961-1986. Data are collected from a public database. It is found that the electricity demand is price inelastic and income elastic. The sales of appliances, as well as the heating degrees-days, are found to have an insignificant effect on electricity demand in contrast with the number of consumers that has a significant effect.

Hondroyiannis (2004) examines the elasticity of price and income in long-run and short-run demand for residential electricity. The examined period is 1986-1999 employing monthly data. In the short-run, the electricity demand is income inelastic and independent of the price, while in the long-run period, all variables, income, price, and weighted average temperature are found to affect electricity demand.

Polemis and Dagoumas (2013) conduct a similar with Hondroyiannis (2004) research. They use cointegration techniques and the vector error correction model to observe the long-run and short-run electricity demand. The data that are taken into account are for a longer period, from 1970 to 2011. In the long-run, the electricity demand is price inelastic and income elastic, while in the short-run the relevant elasticities are inelastic.

Sardianou (2007) investigates the determinants of household energy conservation. The analysis is based on a survey that has been conducted in 586 households of five main Athens' regions. One of the findings is that people with higher income that own their houses, and have a large family are more willing to conserve energy. Also, the number of rooms, the dwelling's size, sex, educational level, and marital status are found that do not have a significant influence in energy conservation. However, it is found that the larger electricity expenditures negatively influence the energy conservation behaviors and the older people are more energy-intensive users than the younger ones.

All variables that have been studied in the above papers are indicated in Tables 6 and 7 in the Appendix section. Tables 6 and 7 also present which of these variables have been studied in this paper.

\section{Method}

\section{Model specification}

The ordinary least squares (OLS) regression is used to estimate the determinants that affect the electricity consumption in Greek households. A variety of studies that examined the determinants of electricity consumption have been conducted using OLS regression (Bedir et al., 2013; Brounen et al., 2012; Filippini \& Pachauri, 2004; Gram-Hanssen, 2011; Halicioglu, 2007; Kavousian et al., 2013; McLoughlin et al., 2012; Ndiaye \& Gabriel, 2011; Sanquist et al., 2012; Sardianou, 2007; Wiesmann et al., 2011). Two different models are employed to determine the electricity consumption. More specifically, a simple OLS regression model and a log-linear regression model are used to build the aforementioned models.

\section{Data sources and description}

Data are collected from a Greek electricity provider and refer only to residential dwellings. Data for the consumption and square meters area have been provided through the actual bills. The period of actual bills is not the same between bills and differs among dwellings. Thus, in order to calculate the consumption with accuracy, the consumption 
per day is calculated at first. Afterwards, consumption per month is calculated and only dwellings that have consumption 2017 are selected.

Demographics and behavior data are retrieved from a questionnaire that was provided through the electricity provider's online platform. The questionnaire was answered from every individual that covers the bill. Only dwellings that already had a monthly consumption for 2017 and have also answered all the questions are selected. The dwellings with invalid values have been excluded from the data, so the final number of dwellings that are included in the analysis is 1801. Table 1 illustrates all available variables, as well as the type and the units of the variables of both models. Table 2 illustrates the summary of statistics of the variables of both models and it shows the levels of ordinal variables and their correspondence to the converted numbers. In addition, the factor type of each variable is indicated.

In the literature review, we have found out that many studies (Donatos \& Mergos, 1991; Kavousian et al., 2013; Ndiaye \& Gabriel, 2011; Sanquist et al., 2012; Wiesmann et al., 2011) include in their models the weather factors of heating degrees-days (HDD) and cooling degrees-days (CDD). HDD and CDD is the difference, in degrees, of outside temperature and base $\left(18.3{ }^{\circ} \mathrm{C}\right)$ temperature. HDD and CDD data for each prefecture and for 2017 have been downloaded from the weather stations of National Observatory of Athens (NOA). Data have been available in the weather website (www. meteo.gr) and have been recorded at a daily basis (Petrou, 2018). The yearly HDD and $\mathrm{CDD}$ have been calculated per prefecture and the weather data are then connected to the consumption data based on prefecture. Units of HDD and CDD are in $1000{ }^{\circ} \mathrm{C}$ days (the values of these variables are big numbers and they should be fitted in the model as in Wiesmann et al., 2011).

The data preparation, manipulation, visualization, and the regression analysis is conducted using programming language $\mathrm{R}$ through RStudio program.

\section{The Model}

Before conducting a regression analysis, an advanced statistical analysis is conducted to observe any associations or correlation between variables. Thus, pairwise comparisons and a correlation analysis (correlation matrix can be found in Table 8 in the Appendix section) are used. The insights of the analysis show a very high negative correlation between HDD and CDD, approximately -0.809 (see Table 8), so HDD is removed from the model. Furthermore, a high correlation between family type and number of occupants is observed, so family type is removed from the model.

In the sample, the final independent variables along with the dummy variables count to thirty three (33). It is essential to determine whether the subset of all independent variables yields to an adequate and appropriate model. Stepwise regression is a method that attempts to find the best regression model, without examining all the possible models (Berenson et al., 2014). There are two approaches of stepwise regression, the "forward selection" and the "backward elimination". Both approaches use the Akaike Information Criterion (AIC) to find the best combination of variables based on balancing the model's complexity and accuracy. The best model is the one with minimum AIC value. The regression model is built using the forward selection, where an initial model is defined that contains only the constant and each independent variable is 


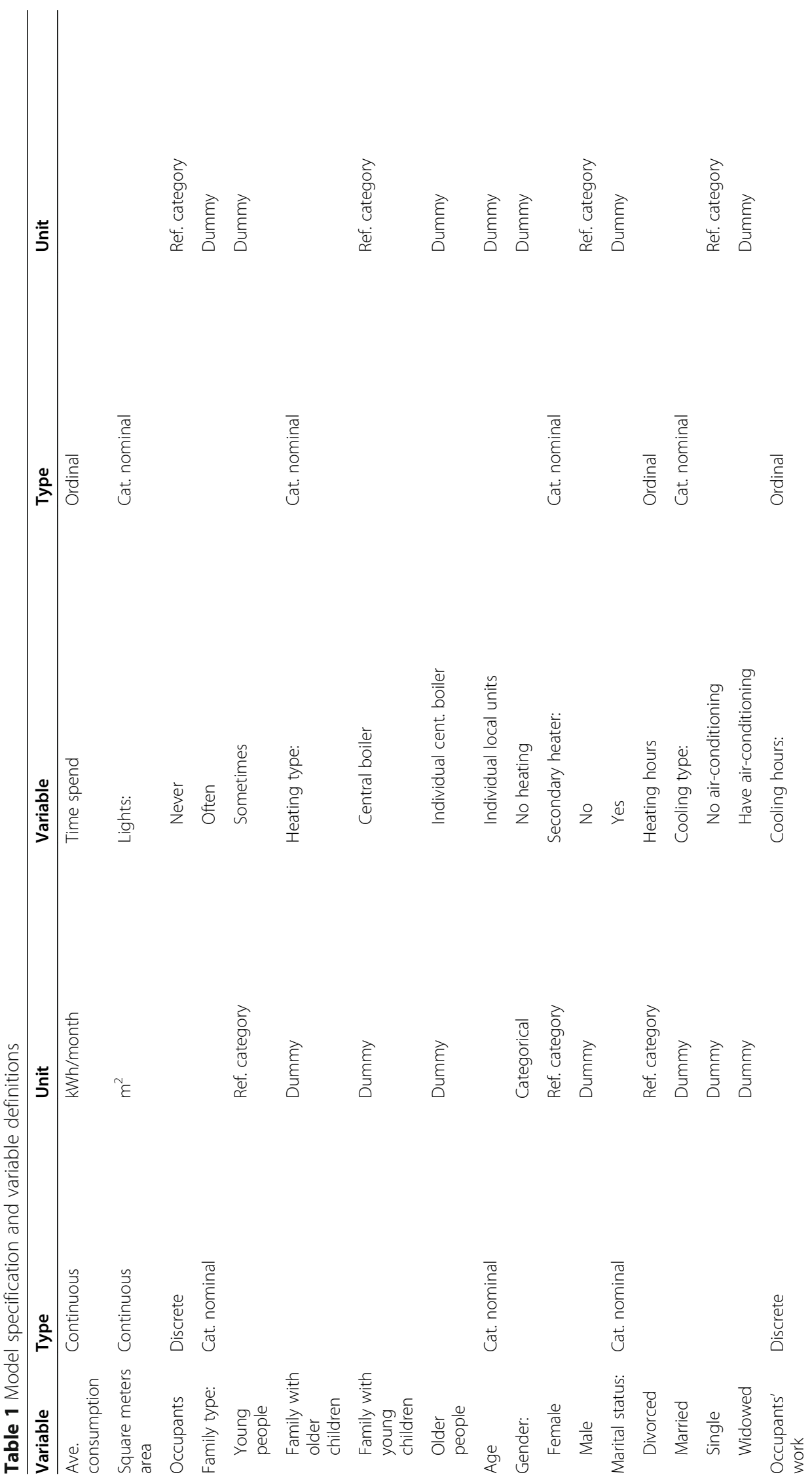




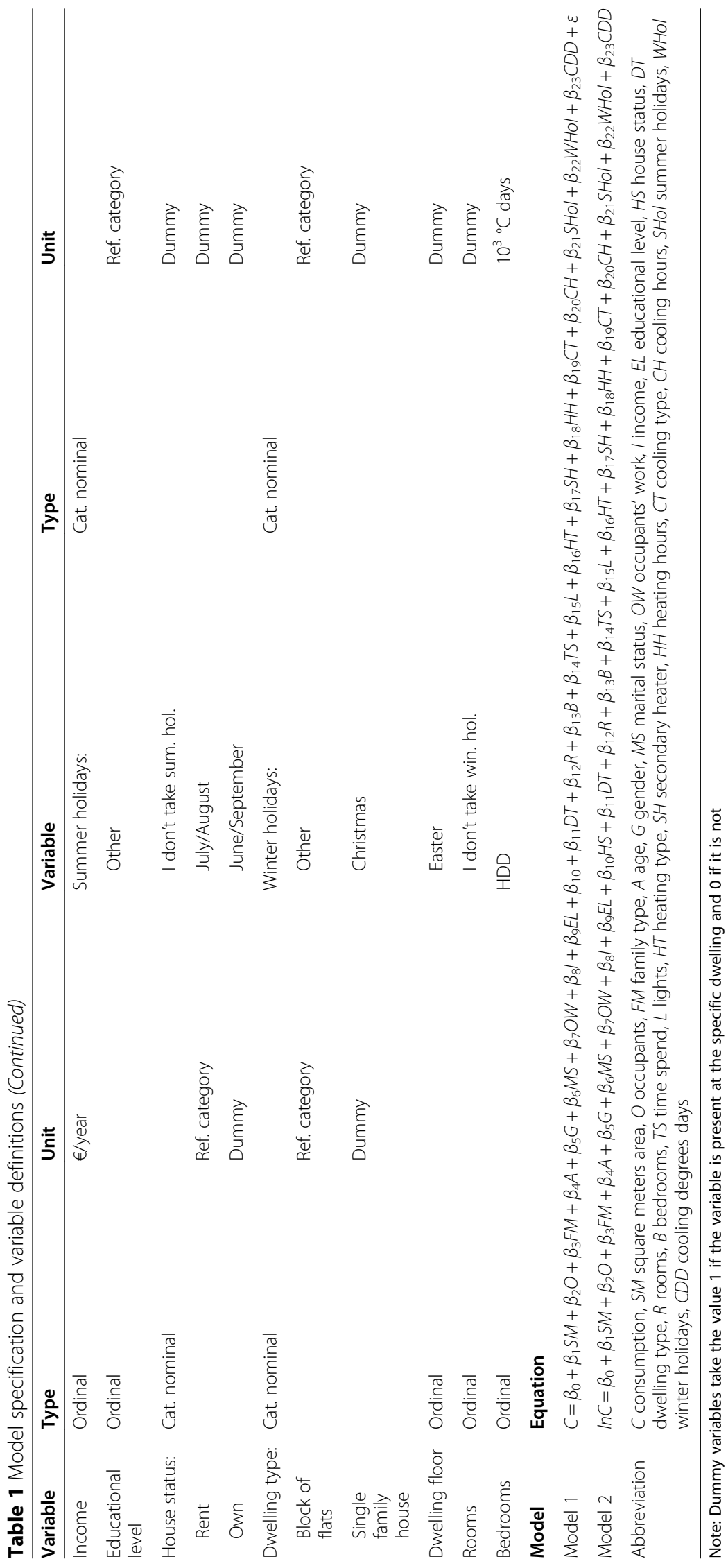


Table 2 Summary statistics of the variables

\begin{tabular}{|c|c|c|c|c|}
\hline Variable & Mean & $\begin{array}{l}\text { St. } \\
\text { Dev. }\end{array}$ & Levels of ordinal variables & $\begin{array}{l}\text { Factor } \\
\text { type }\end{array}$ \\
\hline Ave. consumption & 396.49 & 223.645 & & \\
\hline Square meters area & 105.429 & 52.416 & & $\begin{array}{l}\text { Dwelling } \\
\text { factor }\end{array}$ \\
\hline Occupants & 3.062 & 1.143 & & $\begin{array}{l}\text { Socio- } \\
\text { economic } \\
\text { factor }\end{array}$ \\
\hline $\begin{array}{l}\text { Family type: family } \\
\text { with older children }\end{array}$ & 0.220 & 0.414 & & $\begin{array}{l}\text { Socio- } \\
\text { economic } \\
\text { factor }\end{array}$ \\
\hline $\begin{array}{l}\text { Family type: family } \\
\text { with young children }\end{array}$ & 0.443 & 0.497 & & $\begin{array}{l}\text { Socio- } \\
\text { economic } \\
\text { factor }\end{array}$ \\
\hline $\begin{array}{l}\text { Family type: older } \\
\text { people }\end{array}$ & 0.091 & 0.287 & & $\begin{array}{l}\text { Socio- } \\
\text { economic } \\
\text { factor }\end{array}$ \\
\hline Age & 2.592 & 0.828 & 1: "19-29", 2: "30-39", 3: "40-55", 4: "56-67", 5: "68+". & $\begin{array}{l}\text { Socio- } \\
\text { economic } \\
\text { factor }\end{array}$ \\
\hline Gender: male ${ }^{a}$ & 0.819 & 0.385 & & $\begin{array}{l}\text { Socio- } \\
\text { economic } \\
\text { factor }\end{array}$ \\
\hline Marital status: married ${ }^{a}$ & 0.778 & 0.416 & & $\begin{array}{l}\text { Socio- } \\
\text { economic } \\
\text { factor }\end{array}$ \\
\hline Marital status: single $\mathrm{a}^{\mathrm{a}}$ & 0.171 & 0.377 & & $\begin{array}{l}\text { Socio- } \\
\text { economic } \\
\text { factor }\end{array}$ \\
\hline $\begin{array}{l}\text { Marital status: } \\
\text { widowed }^{\mathrm{a}}\end{array}$ & 0.008 & 0.091 & & $\begin{array}{l}\text { Socio- } \\
\text { economic } \\
\text { factor }\end{array}$ \\
\hline Occupants' work & 1.532 & 0.702 & & $\begin{array}{l}\text { Socio- } \\
\text { economic } \\
\text { factor }\end{array}$ \\
\hline Income & 2.253 & 0.857 & $\begin{array}{l}\text { 1: Low-income (less than 10,000€), 2: Lower-middle } \\
\text { (11,000€-20,000€), 3: Upper-middle (21,000€-40,000€), } \\
\text { 4: High-income (more than } 41,000 €)\end{array}$ & $\begin{array}{l}\text { Socio- } \\
\text { economic } \\
\text { factor }\end{array}$ \\
\hline Educational level & 2.835 & 0.831 & $\begin{array}{l}\text { 1: "No diploma", 2: "High school diploma or } \\
\text { equivalent", 3: "Bachelor or equivalent", 4: "Master or } \\
\text { equivalent", 5: "Doctoral or equivalent" }\end{array}$ & $\begin{array}{l}\text { Socio- } \\
\text { economic } \\
\text { factor }\end{array}$ \\
\hline House status: own ${ }^{\mathrm{a}}$ & 0.721 & 0.449 & & $\begin{array}{l}\text { Dwelling } \\
\text { factor }\end{array}$ \\
\hline $\begin{array}{l}\text { Dwelling type: block of } \\
\text { flats }^{\mathrm{a}}\end{array}$ & 0.710 & 0.454 & & $\begin{array}{l}\text { Dwelling } \\
\text { factor }\end{array}$ \\
\hline $\begin{array}{l}\text { Dwelling type: single } \\
\text { family house }^{a}\end{array}$ & 0.290 & 0.454 & & $\begin{array}{l}\text { Dwelling } \\
\text { factor }\end{array}$ \\
\hline Dwelling floor & 2.189 & 0.813 & 1: "1-2", 2: "3-4", 3: "5-6", 4: "7-8" & $\begin{array}{l}\text { Dwelling } \\
\text { factor }\end{array}$ \\
\hline Rooms & 2.149 & 0.635 & 1: "1-2", 2: "3-4", 3: "5 or more" & $\begin{array}{l}\text { Dwelling } \\
\text { factor }\end{array}$ \\
\hline Bedrooms & 1.919 & 0.416 & 1: "1", 2: "2-3", 3: "4 or more" & $\begin{array}{l}\text { Dwelling } \\
\text { factor }\end{array}$ \\
\hline Time spend & 2.212 & 0.548 & $\begin{array}{l}\text { 1: "Less than half-day", 2: "Half-day or more", 3: "All } \\
\text { day" }\end{array}$ & $\begin{array}{l}\text { Socio- } \\
\text { economic } \\
\text { factor }\end{array}$ \\
\hline Lights: often ${ }^{a}$ & 0.043 & 0.202 & & $\begin{array}{l}\text { Dwelling } \\
\text { factor }\end{array}$ \\
\hline
\end{tabular}


Table 2 Summary statistics of the variables (Continued)

\begin{tabular}{|c|c|c|c|c|}
\hline Variable & Mean & $\begin{array}{l}\text { St. } \\
\text { Dev. }\end{array}$ & Levels of ordinal variables & $\begin{array}{l}\text { Factor } \\
\text { type }\end{array}$ \\
\hline Lights: sometimes $^{a}$ & 0.400 & 0.490 & & $\begin{array}{l}\text { Dwelling } \\
\text { factor }\end{array}$ \\
\hline $\begin{array}{l}\text { Heating type: } \\
\text { individual central } \\
\text { boiler }^{\mathrm{a}}\end{array}$ & 0.503 & 0.500 & & $\begin{array}{l}\text { Dwelling } \\
\text { factor }\end{array}$ \\
\hline $\begin{array}{l}\text { Heating type: } \\
\text { individual local units }\end{array}$ & 0.284 & 0.451 & & $\begin{array}{l}\text { Dwelling } \\
\text { factor }\end{array}$ \\
\hline $\begin{array}{l}\text { Heating type: no } \\
\text { heating }\end{array}$ & 0.053 & 0.224 & & $\begin{array}{l}\text { Dwelling } \\
\text { factor }\end{array}$ \\
\hline Secondary heater: yes ${ }^{a}$ & 0.722 & 0.448 & & $\begin{array}{l}\text { Dwelling } \\
\text { factor }\end{array}$ \\
\hline Heating hours & 2.351 & 0.911 & 1:"0-2 h", 2:"2-5 h", 3:"5-10 h", 4:"10 h or more" & $\begin{array}{l}\text { Dwelling } \\
\text { factor }\end{array}$ \\
\hline $\begin{array}{l}\text { Cooling type: have air- } \\
\text { conditioninga }^{\mathrm{a}}\end{array}$ & 0.870 & 0.336 & & $\begin{array}{l}\text { Dwelling } \\
\text { factor }\end{array}$ \\
\hline Cooling hours $^{a}$ & 1.809 & 0.832 & 1:"0-2 h", 2: "2-5 h", 3: "5-10 h", 4:"10 h or more" & $\begin{array}{l}\text { Dwelling } \\
\text { factor }\end{array}$ \\
\hline $\begin{array}{l}\text { Summer holidays: I } \\
\text { don't take summer } \\
\text { holid. }\end{array}$ & 0.154 & 0.361 & & $\begin{array}{l}\text { Socio- } \\
\text { economic } \\
\text { factor }\end{array}$ \\
\hline $\begin{array}{l}\text { Summer holidays: July/ } \\
\text { August }^{a}\end{array}$ & 0.668 & 0.471 & & $\begin{array}{l}\text { Socio- } \\
\text { economic } \\
\text { factor }\end{array}$ \\
\hline $\begin{array}{l}\text { Summer holidays: } \\
\text { June/September }\end{array}$ & 0.087 & 0.281 & & $\begin{array}{l}\text { Socio- } \\
\text { economic } \\
\text { factor }\end{array}$ \\
\hline $\begin{array}{l}\text { Winter holidays: } \\
\text { Christmas }^{\mathrm{a}}\end{array}$ & 0.234 & 0.424 & & $\begin{array}{l}\text { Socio- } \\
\text { economic } \\
\text { factor }\end{array}$ \\
\hline Winter holidays: Easter ${ }^{a}$ & 0.082 & 0.275 & & $\begin{array}{l}\text { Socio- } \\
\text { economic } \\
\text { factor }\end{array}$ \\
\hline $\begin{array}{l}\text { Winter holidays: I don't } \\
\text { take winter holid. }{ }^{\text {. }}\end{array}$ & 0.527 & 0.499 & & $\begin{array}{l}\text { Socio- } \\
\text { economic } \\
\text { factor }\end{array}$ \\
\hline CDD (1000) & 1.233 & 0.233 & & $\begin{array}{l}\text { Weather } \\
\text { factor }\end{array}$ \\
\hline HDD (1000) & 1.113 & 0.397 & & $\begin{array}{l}\text { Weather } \\
\text { factor }\end{array}$ \\
\hline
\end{tabular}

${ }^{\text {aDummy variable }}$

retained in the model only if it improves the ability of the model to predict the dependent variable.

\section{Results and discussion}

\section{The OLS regression method}

The results of the OLS regressions are presented in Table 3. In general, the results from both models are in agreement with the literature, as it will be indicated in this section. Most of the significant variables are common in both models, but there are variables that influence one model and not the other. The log-linear model (model 2) has better goodness of fit from the linear model, in terms of the $R^{2}$. Both models explain 
Table 3 Estimation results from OLS regression model

\begin{tabular}{lll}
\hline Variable & $\begin{array}{l}\text { Model } 1 \\
\text { Ave. consumption }\end{array}$ & $\begin{array}{l}\text { Model } 2 \\
\text { log(Ave. consumption) }\end{array}$ \\
\hline Squ. meter area & $1.389^{* *}(0.096)$ & $0.003^{* * *}(0.0002)$ \\
Heating hours & $36.760^{* * *}(5.537)$ & $0.075^{* * *}(0.013)$ \\
Occupants & $41.054^{* * *}(4.211)$ & $0.132^{* * *}(0.010)$ \\
Heating type: individual central boiler & $-17.433(12.890)$ & $-0.016(0.031)$ \\
Heating type: individual local units & $46.011^{* * *}(14.447)$ & $0.093^{* * *}(0.035)$ \\
Heating type: no heating & $11.460(22.608)$ & $0.003(0.055)$ \\
Cooling hours & $20.100^{* * *}(5.808)$ & $0.058^{* * *}(0.015)$ \\
Time spend: half-day or more & & $-0.067^{* * *}(0.025)$ \\
Time spend: less than half-day & & $-0.184^{* * *}(0.047)$ \\
Cooling type: no air-conditioning & & $-0.090^{* *}(0.035)$ \\
Age & $18.028^{* * *}(5.502)$ & $0.033^{* *}(0.013)$ \\
Secondary heater: yes & $28.585^{* * *}(10.182)$ & $0.074^{* * *}(0.025)$ \\
Dwelling type: single family house & $23.868^{* *}(10.716)$ & \\
CDD & $44.644^{* *}(20.785)$ & $0.106^{* *}(0.051)$ \\
Constant & $-132.703^{* * *}(37.733)$ & $4.633^{* * *}(0.100)$ \\
Observations & 1,801 & 1,801 \\
$R^{2}$ & 0.290 & 0.297 \\
Adjusted $R^{2}$ & 0.286 & 0.292 \\
Residual Std. error & $189.006(\mathrm{df}=1789)$ & $0.458(\mathrm{df}=1787)$ \\
$F$ statistic & $66.475^{* * *}(\mathrm{df}=11 ; 1789)$ & $58.086^{* * *}(\mathrm{df}=13 ; 1787)$ \\
\hline
\end{tabular}

Note: ${ }^{*} p<0.1 ;{ }^{* *} p<0.05 ;{ }^{* *} p<0.01$

approximately $30 \%$ of the variance in electricity consumption. Even if this value does not seem satisfactory for a regression analysis, when comparing to the literature the $R^{2}$ is within the range published. Indeed, in Sardianou (2007), $R^{2}$ is approximately $10 \%$; in Wiesmann et al. (2011), $R^{2}$ is approximately $33 \%$; in Bedir et al. (2013), $R^{2}$ is approximately 50\%; and in most other papers presented in the literature review, the $R^{2}$ value has not been given. One basic reason for this low value is that even though we have studied thirty-three variables (most given by the electricity provider and others found by the authors), more parameters need to be studied.

Square meters area has a significant effect on the average monthly electricity consumption in both models. To be more specific, if the square meters area increases by $1 \mathrm{~m}^{2}$ then an increase of $1.389 \mathrm{kWh} /$ month according to model 1 and an increase on average yearly consumption by $0.3 \%$ according to model 2 are expected. These results are in line with previous studies (Bedir et al., 2013; Filippini \& Pachauri, 2004; Gram-Hanssen, 2011; Jones et al., 2015; Kavousian et al., 2013; Tewathia, 2014; Wiesmann et al., 2011).

Number of occupants is strongly related with the electricity consumption (because of high beta coefficient and $p$-value $<0.01)$. In both models, more occupants consume more electricity. Studies of Gram-Hanssen (2011), Jones et al. (2015), Kavousian et al. (2013), and Ndiaye and Gabriel (2011) reach the same conclusion.

Heating hours, heating type, and the presence of secondary heaters have a significant positive effect on electricity consumption in both models. That is, heating hours 
influence the electricity consumption regardless the heating type. On the other hand, heating type of local units significantly influences the electricity consumption. Dwellings that use local units for heating the space seem to consume more electricity. The results reveal that houses with heating type of local units use possibly electrical appliances to heat their space which has an impact on their total consumption. The presence of secondary heaters has also a significant positive effect on the electricity consumption. Those results enhance the perspective that the electrical appliances used to heat the space have an impact on electricity consumption. Jones et al. (2015) mention that there are eight studies that found a positive effect of presence of electric space heating system on electricity consumption.

Cooling hours is also related with the electricity consumption. Both models agree to the positive relationship between cooling hours and electricity consumption, as expected. CDD also is found that has a positive effect on electricity consumption in both models. The presence of air-conditioning to cool the space has a significant effect in model 2 while in model 1 it is not found that influences the electricity consumption. This result is aligned with the literature review presented by Jones et al. (2015), since they present studies with both results.

According to model 1, the dwelling type has a significant effect on electricity consumption, as the single family houses seem to consume more electricity. This result is aligned with past studies of Bedir et al. (2013), Brounen et al. (2012), McLoughlin et al. (2012), and Wiesmann et al. (2011).

Both models reveal that the age of inhabitants positively influences the electricity consumption. So, as long as the occupants that cover the bill are elderly, the more electricity is consumed. This result is aligned with and also mentioned that there are eight studies that marked the positive effect of age of head of the household on the electricity consumption.

According to model 2, dwellings with occupants that spent more time in home are found to have a positive significant effect on electricity consumption, as it is expected and it is aligned with Ndiaye and Gabriel (2011) and Tewathia (2014), respectively.

Many variables of the collected data are found that have no significant influence on the electricity consumption. Those variables are gender, educational level, house status, marital status, dwelling floor, income, light behavior, and summer holidays.

As mentioned above, most of the variables that are found significant are common in both models, but there are variables that influence one model and not the other. This happens because in model 2 a non-linear relationship exists between the independent and dependent variables.

\section{Two-stage least squares method (2SLS)}

It is possible that a two-way causation exists between variables of the above models; thus, there is the need to test for endogeneity. Variables that are tested for endogeneity are those of square meter area, number of occupants, and heating hours. Square meter area is found as significant at the level of 10\%; thus, 2SLS is conducted with endogenous variable the square meters area. Number of bedrooms and number of rooms have been inserted in the model as instrumental variables. Tables 4 and 5 illustrate the results of OLS, first stage of 2SLS and second stage of 2SLS for model 1 and model 2, respectively. The coefficients of square meter area and other variables have been fitted and the significant variables are the same with the OLS method. 
Table 4 Estimation results from 2SLS model 1

\begin{tabular}{|c|c|c|c|}
\hline Dependent variable: & $\begin{array}{l}\text { OLS estimation } \\
\text { Ave. consumption }\end{array}$ & $\begin{array}{l}\text { 2SLS estimation-first } \\
\text { stage } \\
\text { Squ. meter area }\end{array}$ & $\begin{array}{l}\text { 2SLS estimation-second } \\
\text { stage } \\
\text { Ave. consumption }\end{array}$ \\
\hline Squ. meter area & $1.389^{* * *}(0.096)$ & & \\
\hline Squ. meter area_hat & & & $1.739 * * *(0.206)$ \\
\hline Heating hours & $36.760^{* * *}(5.537)$ & $5.022^{* * *}(1.209)$ & $34.778^{* * *}(5.654)$ \\
\hline Occupants & $41.054^{* * *}(4.211)$ & $2.616^{* * *}(0.970)$ & $37.367^{* * *}(4.646)$ \\
\hline $\begin{array}{l}\text { Heating type: individual central } \\
\text { boiler }\end{array}$ & $-17.433(12.890)$ & $5.673^{* *}(2.824)$ & $-20.316(13.025)$ \\
\hline $\begin{array}{l}\text { Heating type: individual local } \\
\text { units }\end{array}$ & $46.011^{* * *}(14.447)$ & $-3.165(3.180)$ & $47.131^{* * *}(14.513)$ \\
\hline Heating type: no heating & $11.460(22.608)$ & $-4.579(4.958)$ & $14.886(22.763)$ \\
\hline Cooling hours & $20.100^{* * *}(5.808)$ & $-2.594^{*}(1.337)$ & $20.739 * * *(5.839)$ \\
\hline Age & $18.028^{* * *}(5.502)$ & $1.081(1.213)$ & $16.671 * * *(5.568)$ \\
\hline Secondary heater: yes & $28.585^{* * *}(10.182)$ & $-1.282(2.253)$ & $28.256^{* * *}(10.221)$ \\
\hline $\begin{array}{l}\text { Dwelling type: single family } \\
\text { house }\end{array}$ & $23.868^{* *}(10.716)$ & $22.279^{* * *}(2.313)$ & $12.061(12.403)$ \\
\hline $\begin{array}{l}\text { Cooling type: no air- } \\
\text { conditioning }\end{array}$ & & $-2.776(3.193)$ & \\
\hline Bedrooms & & $42.101^{* * *}(2.934)$ & \\
\hline Rooms & & $16.977^{* * *}(1.816)$ & \\
\hline CDD & $44.644^{* *}(20.785)$ & $12.749^{* * *}(4.573)$ & $40.139 *(20.995)$ \\
\hline Constant & $-132.703^{* * *}(37.733)$ & $-52.396^{* * *}(9.422)$ & $-141.065^{* * *}(38.125)$ \\
\hline Observations & 1801 & 1801 & 1801 \\
\hline$R^{2}$ & 0.290 & 0.381 & 0.285 \\
\hline Adjusted $R^{2}$ & 0.286 & 0.376 & 0.280 \\
\hline Residual Std. error & $189.006(\mathrm{df}=1789)$ & $41.402(\mathrm{df}=1787)$ & $189.710(\mathrm{df}=1789)$ \\
\hline F statistic & $\begin{array}{l}66.475^{* * *}(\mathrm{df}=11 \\
1789)\end{array}$ & $84.476^{* * *}(\mathrm{df}=13 ; 1787)$ & \\
\hline
\end{tabular}

Note: ${ }^{*} p<0.1 ;{ }^{* *} p<0.05 ;{ }^{* * *} p<0.01$

\section{Conclusions}

This study focuses on the investigation of the socio-economic determinants, the dwellings characteristics, and the climatic conditions that influence the household electricity consumption. Two regression models, one linear and one log-linear, are built and the results have been presented in the previous section. The two-stage last squares method (TSLS) is used to explore the two-way causation of squared meter area. Most significant variables are the number of occupants, the size of the dwelling, the heating type, the heating and cooling hours, and the weather conditions. The results of this study are aligned with the ones presented in the literature review.

When acknowledging the conclusions of this analysis, policy makers could use suitable incentives to motivate customers to reduce their electricity consumption. The variables regarding heating and cooling the space are found as significant in both models. A good practice would be for the government to motivate people to renovate their houses in order to maintain the houses' temperature and as a consequence it could reduce the cooling and heating electricity demand. As it is shown from this study, in Greece, houses use electricity to heat their spaces and in many cases they use secondary heaters. Thus, another measure could be to give a subsidy 
Table 5 Estimation results from 2SLS model 2

\begin{tabular}{|c|c|c|c|}
\hline \multirow[t]{2}{*}{ Dependent variable: } & \multirow{2}{*}{$\begin{array}{l}\text { OLS estimation } \\
\text { log(Ave. } \\
\text { consumption) }\end{array}$} & \multirow{2}{*}{$\begin{array}{l}\text { 2SLS estimation-first } \\
\text { stage } \\
\text { Squ. meter area }\end{array}$} & \multirow{2}{*}{$\begin{array}{l}\text { 2SLS estimation-second } \\
\text { stage } \\
\text { log(Ave. consumption) }\end{array}$} \\
\hline & & & \\
\hline Squ. meter area & $0.003^{* * *}(0.0002)$ & & $0.005^{* * *}(0.0005)$ \\
\hline Occupants & $0.132^{* * *}(0.010)$ & $2.616^{* * *}(0.970)$ & $0.111^{* * *}(0.011)$ \\
\hline Heating hours & $0.075^{* * *}(0.013)$ & $5.022^{* * *}(1.209)$ & $0.058^{* * *}(0.014)$ \\
\hline Cooling hours & $0.058^{* * *}(0.015)$ & $-2.594^{*}(1.337)$ & $0.065^{* * *}(0.015)$ \\
\hline Time spend: half-day or more & $-0.067^{* * *}(0.025)$ & & $-0.077^{* * *}(0.026)$ \\
\hline Time spend: less than half-day & $-0.184^{* * *}(0.047)$ & & $-0.181^{* * *}(0.048)$ \\
\hline $\begin{array}{l}\text { Cooling type: no air- } \\
\text { conditioning }\end{array}$ & $-0.090^{* *}(0.035)$ & $-2.776(3.193)$ & $-0.082^{* *}(0.036)$ \\
\hline Bedrooms & & $42.101^{* * *}(2.934)$ & \\
\hline Rooms & & $16.977^{* * *}(1.816)$ & \\
\hline Secondary heater: yes & $0.074^{* * *}(0.025)$ & $-1.282(2.253)$ & $0.076^{* * *}(0.025)$ \\
\hline $\begin{array}{l}\text { Heating type: individual central } \\
\text { boiler }\end{array}$ & $-0.016(0.031)$ & $5.673^{* *}(2.824)$ & $-0.031(0.032)$ \\
\hline $\begin{array}{l}\text { Heating type: individual local } \\
\text { units }\end{array}$ & $0.093^{* * *}(0.035)$ & $-3.165(3.180)$ & $0.102^{* * *}(0.036)$ \\
\hline Heating type: no heating & $0.003(0.055)$ & $-4.579(4.958)$ & $0.012(0.056)$ \\
\hline CDD & $0.106^{* *}(0.051)$ & $12.749^{* * *}(4.573)$ & $0.092^{*}(0.052)$ \\
\hline $\begin{array}{l}\text { Dwelling type: single family } \\
\text { house }\end{array}$ & & $22.279^{* * *}(2.313)$ & \\
\hline Age & $0.033^{* *}(0.013)$ & $1.081(1.213)$ & $0.022(0.014)$ \\
\hline Constant & $4.633^{* * *}(0.100)$ & $-52.396^{* * *}(9.422)$ & $4.585^{* * *}(0.102)$ \\
\hline Observations & 1,801 & 1,801 & 1,801 \\
\hline$R^{2}$ & 0.297 & 0.381 & 0.270 \\
\hline Adjusted $R^{2}$ & 0.292 & 0.376 & 0.265 \\
\hline Residual Std. error $(\mathrm{df}=1787$ ) & 0.458 & 41.402 & 0.467 \\
\hline F Statistic (df = 13; 1787) & $58.086^{* * *}$ & $84.476^{* * *}$ & \\
\hline
\end{tabular}

Note: ${ }^{*} p<0.1 ;{ }^{* *} p<0.05 ;{ }^{* *} p<0.01$

to urge consumers to change their heating systems to more efficient and cheaper ones, such as natural gas boilers.

Another strategy that policy makers could follow is to incentivize electricity providers for the electricity per hh reduction. The utilities then could provide a discount to those households that achieve an electricity reduction year by year. Thus, both utilities and consumers will win from this strategy. The customers will have the incentive of lower cost and will try to reduce their consumption.

Simultaneously, government and utilities could enhance and promote the usage of new technology electricity appliances, such as smart appliances and appliances with A++ energy label, that consume less electricity. By large campaigns, the consumers could be informed about how they can save if they change their old wasteful appliances.

To conclude, this research shows that the dwelling and household characteristics, as well as the climatic conditions, are essential predictors in models of electricity consumption. Further research on occupants' behavior and on presence and functions of appliances will enhance the determinants of electricity consumption in housing. 


\section{Appendix}

Table 6 Variables studied in the literature as it is presented in the "Literature review" section and variables that are analyzed in this study

\begin{tabular}{|c|c|c|c|}
\hline $\mathrm{a} / \mathrm{a}$ & Variable & Studies that consider the variable & $\begin{array}{l}\text { This study } \\
\text { considers } \\
\text { the variable }\end{array}$ \\
\hline 1 & Number of occupants & $\begin{array}{l}\text { Wiesmann et al., 2011; Brounen et al., 2012; } \\
\text { Gram-Hanssen, 2011; Esmaeilimoakher et al., } \\
\text { 2016; Sanquist et al., 2012; Ndiaye \& Gabriel, } \\
\text { 2011; Tewathia, 2014; Sardianou, } 2007\end{array}$ & $\checkmark$ \\
\hline 2 & Number/ Presence of children & $\begin{array}{l}\text { Wiesmann et al., 2011; Bedir et al., 2013; } \\
\text { Brounen et al., 2012; Gram-Hanssen, 2011; } \\
\text { Esmaeilimoakher et al., } 2016\end{array}$ & $\checkmark$ \\
\hline 3 & Number/Presence of teenagers & Brounen et al., 2012; Gram-Hanssen, 2011 & $\checkmark$ \\
\hline 4 & Number/Presence of adults & McLoughlin et al., 2012 & $\checkmark$ \\
\hline 5 & $\begin{array}{l}\text { Number/Presence of elderly people } \\
\text { (over } 65 \text { years old) }\end{array}$ & $\begin{array}{l}\text { McLoughlin et al., 2012; Bedir et al., 2013; } \\
\text { Brounen et al., 2012; Gram-Hanssen, } 2011\end{array}$ & $\checkmark$ \\
\hline 6 & Age of Household Reference Person (HRP) & $\begin{array}{l}\text { McLoughlin et al., 2012; Bedir et al., 2013; } \\
\text { Brounen et al., 2012; Gram-Hanssen, 2011; } \\
\text { Esmaeilimoakher et al., 2016; Ndiaye \& Gab- } \\
\text { riel, 2011; Sardianou, 2007; }\end{array}$ & $\checkmark$ \\
\hline 7 & Age of children & Ndiaye and Gabriel (2011) & $\checkmark$ \\
\hline 8 & Gender of Household Reference Person & $\begin{array}{l}\text { Esmaeilimoakher et al., 2016; Sardianou, } \\
2007\end{array}$ & $\checkmark$ \\
\hline 9 & Marital status of occupants & Sardianou, 2007 & $\checkmark$ \\
\hline 10 & Employment status of HRP & Bedir et al., 2013 & \\
\hline 11 & $\begin{array}{l}\text { Hours of occupancy (or number of } \\
\text { occupants work or stay at home) }\end{array}$ & $\begin{array}{l}\text { Bedir et al., 2013; Ndiaye \& Gabriel, 2011; } \\
\text { Polemis \& Dagoumas, } 2013\end{array}$ & $\checkmark$ \\
\hline 12 & Time spend outside/inside home & Esmaeilimoakher et al., 2016; Tewathia, 2014 & $\checkmark$ \\
\hline 13 & Education level of HRP & $\begin{array}{l}\text { Bedir et al., 2013; Gram-Hanssen, 2011; } \\
\text { Ndiaye \& Gabriel, 2011; Tewathia, 2014; Sar- } \\
\text { dianou, } 2007\end{array}$ & $\checkmark$ \\
\hline 14 & Social classification of HRP & McLoughlin et al., 2012 & \\
\hline 15 & Family type & $\begin{array}{l}\text { Wiesmann et al., 2011; McLoughlin et al., } \\
\text { 2012; Brounen et al., } 2012\end{array}$ & $\checkmark$ \\
\hline 16 & Fraction of females in household & Brounen et al., 2012 & \\
\hline 17 & Occupied by foreign-born & Brounen et al., 2012; Ndiaye \& Gabriel, 2011 & \\
\hline 18 & Income & $\begin{array}{l}\text { Wiesmann et al., 2011; Bedir et al., 2013; } \\
\text { Brounen et al., 2012; Gram-Hanssen, 2011; } \\
\text { Halicioglu, 2007; Esmaeilimoakher et al., } \\
\text { 2016; Ndiaye \& Gabriel, 2011; Tewathia, } \\
\text { 2014; Donatos \& Mergos, 1991; Hondroyian- } \\
\text { nis, 2004; Sardianou, } 2007\end{array}$ & $\checkmark$ \\
\hline 19 & Dwelling type & $\begin{array}{l}\text { Wiesmann et al., 2011; Bedir et al., 2013; } \\
\text { McLoughlin et al., 2012; Brounen et al., 2012; } \\
\text { Gram-Hanssen, 2011; Esmaeilimoakher et al., } \\
\text { 2016; Ndiaye \& Gabriel, } 2011\end{array}$ & $\checkmark$ \\
\hline 20 & Dwelling age & $\begin{array}{l}\text { Wiesmann et al., 2011; Brounen et al., 2012; } \\
\text { Esmaeilimoakher et al., 2016; Sanquist et al., } \\
\text { 2012; Ndiaye \& Gabriel, 2011; }\end{array}$ & \\
\hline 21 & Dwellings per building or Dwellings density & Wiesmann et al., 2011 & \\
\hline 22 & Dwelling size & $\begin{array}{l}\text { Bedir et al., 2013; Brounen et al., 2012; } \\
\text { Gram-Hanssen, 2011; Esmaeilimoakher et al., } \\
\text { 2016; Tewathia, } 2014\end{array}$ & $\checkmark$ \\
\hline
\end{tabular}


Table 6 Variables studied in the literature as it is presented in the "Literature review" section and variables that are analyzed in this study (Continued)

\begin{tabular}{|c|c|c|c|}
\hline$a / a$ & Variable & Studies that consider the variable & $\begin{array}{l}\text { This study } \\
\text { considers } \\
\text { the variable }\end{array}$ \\
\hline 23 & Number of rooms & $\begin{array}{l}\text { Wiesmann et al., 2011; Bedir et al., 2013; } \\
\text { Brounen et al., 2012; Sardianou, } 2007\end{array}$ & $\checkmark$ \\
\hline 24 & Number of bedrooms & $\begin{array}{l}\text { McLoughlin et al., 2012; Bedir et al., 2013; } \\
\text { Esmaeilimoakher et al., } 2016\end{array}$ & $\checkmark$ \\
\hline 25 & Number of study rooms & Bedir et al., 2013 & \\
\hline 26 & $\begin{array}{l}\text { Dwelling floor (in case of apartment } \\
\text { building) }\end{array}$ & & $\checkmark$ \\
\hline 27 & Heating system & $\begin{array}{l}\text { Bedir et al., 2013; Brounen et al., 2012; } \\
\text { Gram-Hanssen, 2011; Ndiaye \& Gabriel, } 2011\end{array}$ & $\checkmark$ \\
\hline 28 & Heating system efficiency & Ndiaye \& Gabriel, 2011 & \\
\hline 29 & Hours of heating per day & & $\checkmark$ \\
\hline 30 & Presence of secondary heater appliances & & $\checkmark$ \\
\hline 31 & Age of the heating system & Ndiaye \& Gabriel, 2011 & \\
\hline 32 & Type of air conditioning system & Ndiaye \& Gabriel, 2011, Sanquist et al., 2012 & \\
\hline 33 & Presence of air conditioning system & Ndiaye \& Gabriel, 2011 & $\checkmark$ \\
\hline 34 & Age of the air conditioning system & Ndiaye \& Gabriel, 2011 & \\
\hline 35 & Hours of cooling per day & & $\checkmark$ \\
\hline 36 & Rented/owner occupied & $\begin{array}{l}\text { Bedir et al., 2013; Ndiaye \& Gabriel, 2011; } \\
\text { Sardianou, } 2007\end{array}$ & $\checkmark$ \\
\hline 37 & Years of residence in the same house & $\begin{array}{l}\text { Bedir et al., 2013; Esmaeilimoakher et al., } \\
2016\end{array}$ & \\
\hline 38 & $\begin{array}{l}\text { Maintenace interior or exterior / Insulation } \\
\text { quality }\end{array}$ & Brounen et al., 2012 & \\
\hline 39 & Heating degrees-days & $\begin{array}{l}\text { Wiesmann et al., 2011; Sanquist et al., 2012; } \\
\text { Donatos \& Mergos, 1991; Polemis \& } \\
\text { Dagoumas, } 2013\end{array}$ & $\checkmark$ \\
\hline 40 & Cooling degrees-days & $\begin{array}{l}\text { Wiesmann et al., 2011; Sanquist et al., 2012; } \\
\text { Polemis \& Dagoumas, } 2013\end{array}$ & $\checkmark$ \\
\hline 41 & Temperature & Hondroyiannis, 2004 & \\
\hline 42 & $\begin{array}{l}\text { Number of hours windows were open in } \\
\text { the dwelling }\end{array}$ & Esmaeilimoakher et al., 2016 & \\
\hline 43 & $\begin{array}{l}\text { Average number of weeks of vacation taken } \\
\text { away from the house each year (or } \\
\text { summer/winder holidays) }\end{array}$ & Ndiaye \& Gabriel, 2011 & $\checkmark$ \\
\hline 44 & $\begin{array}{l}\text { Household awareness (The education level } \\
\text { of the head of the household is used as a } \\
\text { proxy for household awareness) }\end{array}$ & Tewathia, 2014 & \\
\hline 45 & Place/Location & $\begin{array}{l}\text { Wiesmann et al., 2011; Tewathia, 2014; } \\
\text { Halicioglu, } 2007\end{array}$ & \\
\hline 46 & Electricity price & $\begin{array}{l}\text { Halicioglu, 2007; Donatos \& Mergos, 1991; } \\
\text { Hondroyiannis, 2004; Polemis \& Dagoumas, } \\
\text { 2013; Sardianou, } 2007\end{array}$ & \\
\hline 47 & $\begin{array}{l}\text { Electricity tariff (can take two values: (1) } \\
\text { single tariff consumption—one daytime and } \\
\text { evening rate on weekdays and weekends, } \\
\text { and ( } 2 \text { ) double tariff consumption-two } \\
\text { different rates, one for during the day and } \\
\text { another for evenings, nights and weekends) }\end{array}$ & Bedir et al., 2013 & \\
\hline 48 & $\begin{array}{l}\text { Price of diesel or LPG (liquefied petroleum } \\
\text { gas) or light fuel }\end{array}$ & $\begin{array}{l}\text { Donatos \& Mergos, 1991; Polemis \& } \\
\text { Dagoumas, } 2013\end{array}$ & \\
\hline
\end{tabular}


Table 6 Variables studied in the literature as it is presented in the "Literature review" section and variables that are analyzed in this study (Continued)

\begin{tabular}{|c|c|c|c|}
\hline$a / a$ & Variable & Studies that consider the variable & $\begin{array}{l}\text { This study } \\
\text { considers } \\
\text { the variable }\end{array}$ \\
\hline 49 & Gross domestic product (GDP) & Polemis \& Dagoumas, 2013 & \\
\hline 50 & Price of electrical appliances & Donatos \& Mergos, 1991 & \\
\hline 51 & Gas consumption, yearly & Bedir et al., 2013 & \\
\hline 52 & $\begin{array}{l}\text { Number of appliances and number of } \\
\text { appliances per group }\end{array}$ & Wiesmann et al., 2011; Bedir et al., 2013 & \\
\hline 53 & $\begin{array}{l}\text { Lights (hours per day light bulbs are on/ } \\
\text { type) or Leave lights on in unoccupied } \\
\text { room }\end{array}$ & Sanquist et al., 2012; Ndiaye \& Gabriel, 2011 & $\checkmark$ \\
\hline 54 & $\begin{array}{l}\text { Use of appliances (Total use of electrical } \\
\text { appliances in a day (in hours)) }\end{array}$ & Tewathia, 2014 & \\
\hline 55 & Number of light bulbs & Bedir et al., 2013 & \\
\hline 56 & Computer (number, use) & Sanquist et al., 2012 & \\
\hline 57 & TV (number) & Sanquist et al., 2012 & \\
\hline 58 & Electric oven (use) & Sanquist et al., 2012 & \\
\hline 59 & Dishwasher (use) & Bedir et al., 2013; Sanquist et al., 2012 & \\
\hline 60 & Washing machine (use) & Bedir et al., 2013; Sanquist et al., 2012 & \\
\hline 61 & Tumble dryer (use) & Bedir et al., 2013; Sanquist et al., 2012 & \\
\hline 62 & Number of showers & Bedir et al., 2013 & \\
\hline 63 & Duration of showers & Bedir et al., 2013 & \\
\hline 64 & Ventilation system & Bedir et al., 2013 & \\
\hline 65 & Water heating type(electric/no electric) & McLoughlin et al., 2012 & \\
\hline 66 & Cooking type (electric/ no electric) & McLoughlin et al., 2012 & \\
\hline 67 & $\begin{array}{l}\text { Efficiency ( } \mathrm{HoH} \text { who believe they can cut } \\
\text { electricity consumption by } x \% \text { ) }\end{array}$ & McLoughlin et al., 2012 & \\
\hline 68 & Number of ceiling fans & Sanquist et al., 2012 & \\
\hline 69 & Cooled area & Sanquist et al., 2012 & \\
\hline
\end{tabular}


Table 7 Low importance variables studied in the literature

\begin{tabular}{|c|c|c|}
\hline$a / a$ & Variable & $\begin{array}{l}\text { Studies that consider } \\
\text { the variable }\end{array}$ \\
\hline 1 & Importance to reduce the amount of energy use & Ndiaye and Gabriel (2011) \\
\hline 2 & Importance to spend less money on energy bills & Ndiaye and Gabriel (2011) \\
\hline 3 & $\begin{array}{l}\text { Feeling of the level of involvement of the government with energy } \\
\text { conservation }\end{array}$ & Ndiaye and Gabriel (2011) \\
\hline 4 & Interest in learning more about ways to save energy in the house & Ndiaye and Gabriel (2011) \\
\hline 5 & $\begin{array}{l}\text { Interest in using an eventual computer software that could serve to } \\
\text { program and control the amount of energy used in the house }\end{array}$ & Ndiaye and Gabriel (2011) \\
\hline 6 & Feeling of the safety of the neighborhood & Ndiaye and Gabriel (2011) \\
\hline 7 & Insecurity and fear of crime & Ndiaye and Gabriel (2011) \\
\hline 8 & $\begin{array}{l}\text { Number of new major energy efficient appliances purchased } \\
\text { over the last } 5 \text { years }\end{array}$ & Ndiaye and Gabriel (2011) \\
\hline 9 & Type of fuel per appliance (oven, cloth dryer, pool heater) & Ndiaye and Gabriel (2011) \\
\hline 10 & Renovation the last 5-10 years & Ndiaye and Gabriel (2011) \\
\hline 11 & Type of fuel for the heating system/water heating & Ndiaye and Gabriel (2011) \\
\hline 12 & Number of floors & Ndiaye and Gabriel (2011) \\
\hline 13 & Presence of window overhangs (in each direction) & Ndiaye and Gabriel (2011) \\
\hline 14 & $\begin{array}{l}\text { Amount willing to spend on a new energy device if it would result in long } \\
\text { term reductions in energy costs }\end{array}$ & Ndiaye and Gabriel (2011) \\
\hline 15 & Effective U-value of windows/doors/walls/ceiling (Btu/h ft2 ${ }^{\circ} \mathrm{F}$ ) & Ndiaye and Gabriel (2011) \\
\hline 16 & Ceiling area & Ndiaye and Gabriel (2011) \\
\hline 17 & Total net exterior wall are & Ndiaye and Gabriel (2011) \\
\hline 18 & Total window area & Ndiaye and Gabriel (2011) \\
\hline 19 & Foundation/Basement wall U-value & Ndiaye and Gabriel (2011) \\
\hline 20 & Number of air changes per hour at $50 \mathrm{~Pa}$ & Ndiaye and Gabriel (2011) \\
\hline 21 & The respondent is informed about the global environmental problems & Sardianou (2007) \\
\hline 22 & The respondent recognizes his contribution to environmental problems & Sardianou (2007) \\
\hline
\end{tabular}


In the following table, the correlation matrix between types of variables is presented. Due to the varying type of variables, a compass correlation matrix is created as follows:

- Continuous/discrete/ordinal pair: Pearson correlation

- Continuous/discrete/categorical pair: correlation coefficient or squared root of $R^{2}$ coefficient of linear regression of integer/numeric variable over factor/categorical variable. The value lies between 0 and 1 .

- Categorical pair: Cramer's V value is computed based on Chi-squared test using. The value lies between 0 and 1 .

The cutoff point is set 0.6. So, the variables of Family type and HDD are omitted from the analysis.

Table 8 Correlation matrix

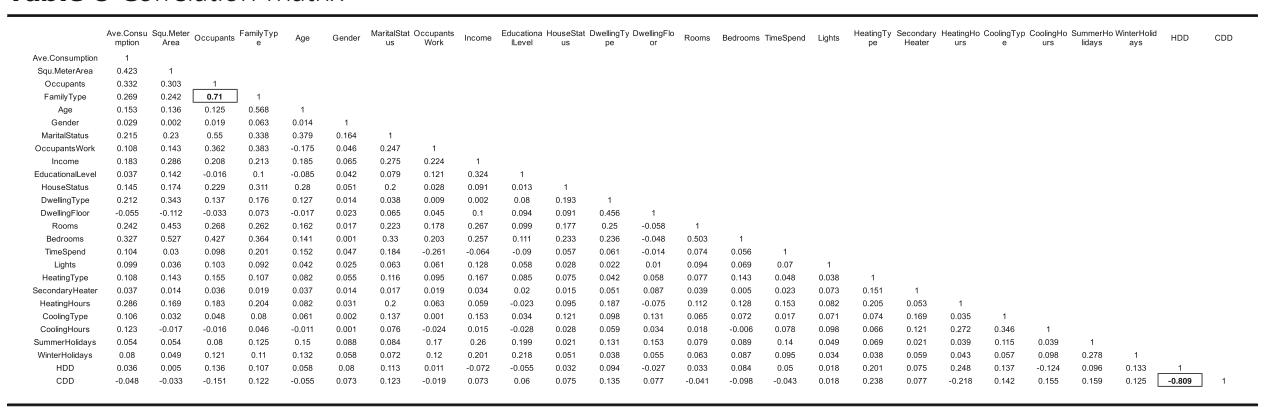

Acknowledgements

Not applicable.

\section{Authors' contributions}

The paper was jointly conceived, developed, and written by both authors. The authors read and approved the final manuscript.

\section{Funding}

The authors declare that they have no funding for their research.

\section{Availability of data and materials}

Data of this study were collected from the database of a Greek electricity provider. The research data cannot be shared publicly, because the individual privacy could be compromised. The authors after the approval of the Greek electricity provider could provide the final data set to a third researcher.

\section{Declarations}

Competing interests

The authors declare that they have no competing interests.

\section{Author details}

${ }^{1}$ Master in Business Administration (MBA), Hellenic Open University, Patras, Greece. ${ }^{2}$ Department of Economics, International Hellenic University, Serres, Greece. ${ }^{3}$ Hellenic Open University, Patras, Greece.

Received: 27 January 2020 Accepted: 4 April 2021

Published online: 06 July 2021

\section{References}

Bedir, M., Hasselaar, E., \& Itard, L. (2013). Determinants of electricity consumption in Dutch dwellings. Energy and Buildings, 58, 194-207. https://doi.org/10.1016/j.enbuild.2012.10.016.

Berenson, M. L., Levine, D. M., \& Szabat, K. A. (2014). Basic business statistics, student value edition, (13th ed., ). Pearson.

Brounen, D., Kok, N., \& Quigley, J. M. (2012). Residential energy use and conservation: Economics and demographics. Green Building, the Economy, and Public Policy, 56(5), 931-945.

DataBank (2020). World development indicators. DataBank Available at: https://data.worldbank.org/indicator/EG.USE.ELEC.KH. $P C$ ?locations=GR (Accessed 20 Oct 2020). 
Donatos, G. S., \& Mergos, G. J. (1991). Residential demand for electricity: The case of Greece. Energy Economics, 13(1), $41-47$. https://doi.org/10.1016/0140-9883(91)90054-4.

Esmaeilimoakher, P., Urmee, T., Pryor, T., \& Baverstock, G. (2016). Identifying the determinants of residential electricity consumption for social housing in Perth, Western Australia. Energy and Buildings, 133, 403-413. https://doi.org/10.1016/j. enbuild.2016.09.063

European Parliament and Council (2009). Directive 2009/28/EC of the European Parliament and of the Council of 23 April 2009 on the promotion of the use of energy from renewable sources and amending and subsequently repealing Directives 2001/77/EC and 2003/30/EC. Official Journal of the European Union, 52(L140), 16-62.

Eurostat. (2018). Energy consumption in households - statistics explained, available at: http://ec.europa.eu/eurostat/statisticsexplained/images/1/16/Energy_consumption_households_final.xlsx (Accessed 26 Apr 2018).

Filippini, M., \& Pachauri, S. (2004). Elasticities of electricity demand in urban Indian households. Energy Policy, 32(3), $429-436$. https://doi.org/10.1016/S0301-4215(02)00314-2.

Gram-Hanssen, K. (2011). Households' energy use - which is the more important: efficient technologies or user practices?, Energy End-Use Efficiency Issues (EEE), (pp. 992-999).

Halicioglu, F. (2007). Residential electricity demand dynamics in Turkey. Energy Economics, 29(2), 199-210. https://doi.org/10.1 016/j.eneco.2006.11.007.

Hondroyiannis, G. (2004). Estimating residential demand for electricity in Greece. Energy Economics, 26(3), 319-334. https://doi. org/10.1016/j.eneco.2004.04.001.

International Energy Agency (2017). Energy policies of IEA Countries, Greece 2017 review, available at: https://euagenda.eu/uploa d/publications/untitled-110952-ea.pdf (accessed 19 October 2020).

International Energy Agency (2020a). CO2 emissions by sector, Greece 1990-2018, available at:https://www.iea.org/data-and-sta tistics?country=GREECE\&fuel=CO2\%20emissions\&indicator=CO2BySector (accessed 19 October 2020).

International Energy Agency (2020b). Electricity generation by source, Greece 1990-2019, available at: https://www.iea.org/data-a nd-statistics?country=GREECE\&fuel=Electricity\%20and\%20heat\&indicator=ElecGenByFuel (Accessed 19 Oct 2020).

International Energy Agency (2020c). Electricity final consumption by sector, Greece 1990-2018, available at: https://www.iea.org/ data-and-statistics?country=GREECE\&fuel=Electricity\%20and\%20heat\&indicator=ElecConsBySector (Accessed 19 Oct 2020).

Jones, R. V., Fuertes, A., \& Lomas, K. J. (2015). The socio-economic, dwelling and appliance related factors affecting electricity consumption in domestic buildings. Renewable and Sustainable Energy Reviews, 43, 901-917. https://doi.org/10.1016/j. rser.2014.11.084

Kavousian, A., Rajagopal, R., \& Fischer, M. (2013). Determinants of residential electricity consumption: Using smart meter data to examine the effect of climate, building characteristics, appliance stock, and occupants' behavior. Energy, 55, 184-194. https://doi.org/10.1016/j.energy.2013.03.086.

McLoughlin, F., Duffy, A., \& Conlon, M. (2012). Characterising domestic electricity consumption patterns by dwelling and occupant socio-economic variables: an Irish case study. Energy and Buildings, 48, 240-248. https://doi.org/10.1016/j. enbuild.2012.01.037.

Ndiaye, D., \& Gabriel, K. (2011). Principal component analysis of the electricity consumption in residential dwellings. Energy and Buildings, 43(2), 446-453. https://doi.org/10.1016/j.enbuild.2010.10.008.

Official Government Gazette. (2018). Accelerating the development of renewable energy sources to deal with climate change and other regulations addressing issues under the authority of the Ministry of Environment, Energy and Climate Change, 3851/ 2010, 1753-1779.

Petrou A.M. J. (2018). "meteo.gr", meteo.gr - weather forecasts for Greece, available at: http://www.meteo.gr/ (Accessed 10 Mar 2018).

Polemis, M. L., \& Dagoumas, A. S. (2013). The electricity consumption and economic growth nexus: Evidence from Greece. Energy Policy, 62, 798-808. https://doi.org/10.1016/j.enpol.2013.06.086.

Sanquist, T. F., Orr, H., Shui, B., \& Bittner, A. C. (2012). Lifestyle factors in U.S. residential electricity consumption. Energy Policy, 42, 354-364. https://doi.org/10.1016/j.enpol.2011.11.092.

Sardianou, E. (2007). Estimating energy conservation patterns of Greek households. Energy Policy, 35(7), 3778-3791. https://doi. org/10.1016/j.enpol.2007.01.020.

Tewathia, N. (2014). Determinants of the household electricity consumption: a case study of Delhi. International Journal of Energy Economics and Policy, 4(3), 337-348.

Wiesmann, D., Lima Azevedo, I., Ferrão, P., \& Fernández, J. E. (2011). Residential electricity consumption in Portugal: findings from top-down and bottom-up models. Energy Policy, 39(5), 2772-2779. https://doi.org/10.1016/j.enpol.2011.02.047.

World Energy Council. (2016). Electricity use per household | Electricity Consumption Efficiency| WEC, available at: https://wecindicators.enerdata.net/xls/household-electricity-use.xls (Accessed 26 Feb 2018).

\section{Publisher's Note}

Springer Nature remains neutral with regard to jurisdictional claims in published maps and institutional affiliations. 